\title{
Neonatal atrial flutter: Three cases and review of the literature
}

\author{
Seda Yilmaz-Semerci ${ }^{1}$, Helen Bornaun ${ }^{2}$, Dilek Kurnaz ${ }^{1}$, Burcu Cebeci ${ }^{1}$, Aslan Babayigit ${ }^{1}$, \\ Gökhan Büyükkale ${ }^{1}$, Merih Çetinkaya ${ }^{1}$ \\ Division of ${ }^{1}$ Neonatology and ${ }^{2}$ Pediatric Cardiology, Department of Pediatrics, Istanbul Kanuni Sultan Suleyman Training \\ and Research Hospital, Istanbul, Turkey. E-mail: sedayilmazsemerci@gmail.com \\ Received: 27th April 2017, Revised: 2nd June 2017, Accepted: 4th June 2017
}

\begin{abstract}
SUMMARY: Yllmaz-Semerci S, Bornaun H, Kurnaz D, Cebeci B, Babayiğit A, Büyükkale G, Cetinkaya M. Neonatal atrial flutter: Three cases and review of the literature. Turk J Pediatr 2018; 60: 306-309.

Atrial flutter (AFl) is known to be a seldom type of fetal and neonatal arrhythmia. Although it could end in severe morbidities such as hydrops fetalis or even death, with early prenatal diagnosis and prompt therapeutic approaches the majority of AFl cases show good prognosis. Neonatal AFl might be resistant to first step therapies. Therefore, secondary agents like flecainide, amiodarone, sotalol and cardioversion, if required, could be influent in perinatal tachyarrhythmia. In addition, close follow-up even after discharge is very important to keep all follow-up appointments. Herein, we present three cases of fetal/neonatal AFl in light of the literature and discuss the characteristics, diagnosis and treatment options.
\end{abstract}

Key words: atrial flutter, newborn, arrhythmia.

Tachycardia is defined as a persistent increase in heart rate above 180 beats/min and bradycardia is described a persistent heart rate less than 100 beats/min for neonates. Asymptomatic and temporary rhythm abnormalities occur constantly at the fetal and neonatal period but clinically significant arrhythmias are considerably rare. The incidence of arrhythmias for neonatal period is about $1 \%$ and $1-3 \%$ in late pregnancy. ${ }^{1}$ The vast majority of supraventricular tachycardia (SVT) seen in neonatal age group without congenital cardiac anomalies are atrioventricular reentry tachycardia (AVRT) facilitated by an accessory pathway (AP) and atrial flutter $(\mathrm{AFl})$ which is seldom encountered outside the neonatal period. The vast majority of these infants get free from symptomatic arrhythmia by the end of the first year of life, although recurrence in later childhood or adolescence is well recognized. Other less common mechanisms include abnormal automaticity, triggered activities are rare in early childhood, becoming more frequent with increasing age. Atrial flutter (AFl) is an uncommon type of fetal and neonatal arrhythmias based on the mechanism of reentry. It constitutes about $32 \%$ of all neonatal cardiac arrhythmias. ${ }^{2}$ There are various etiologic factors for AFL. Although it may be asymptomatic, it may even result with severe heart failure requiring urgent therapy. ${ }^{1}$ AFI cases are not accompanied by structural heart diseases generally. However, AFl cases that occur after first year of life are usually secondary to cardiac surgical procedures. ${ }^{3,4}$ AFI is usually diagnosed by electrocardiogram (ECG) with the presence of typical saw like waves of flutter. Atrial rates vary between 280450 beats per minute (BPM).5,6 Majority of the cases are converted to sinusoidal rhythm easily by the usage of antiarrhythmic drugs or cardioversion. ${ }^{3,7}$ Although neonatal arrhythmias have relatively good prognosis, regular followup of the patients is crucial to prevent possible complications. Herein, we report three fetal/ neonatal cases managed successfully with antiarrhythmic medications and cardioversion. The aim of this study was to determine the possible risk factors, treatment options and prognosis for these cases. We also reviewed the literature about AFI in newborns.

An informed consent was received from the parents.

\section{Case Reports}

Case 1

A term male infant with a birth weight of 2,560 g was delivered by Cesarean section of 
a 23-year-old primiparous mother. The APGAR scores were 9 and 10 at 1 st and 5th minutes, respectively. In prenatal history, fetal arrhythmia was detected (Fig. 1). His heart rate was detected as 225 beats per minute (bpm) at the first physical examination. ECG demonstrated 2-3:1 atrioventricular conduction AFl (atrial rate $485 / \mathrm{bpm}$, ventricular rate $225 / \mathrm{bpm}$ ) (Fig. $2)$. Therefore, oral propranolol therapy with a dosage of $2 \mathrm{mg} / \mathrm{kg} /$ day was started. Ejection fraction (EF) was $60 \%$. Due to the recurrence of $\mathrm{AFl}$, cardioversion was performed with 1 joule $/ \mathrm{kg}$ and the rhythm converted to normal. At the follow up, propranolol was stopped due to the frequent recurrent AFI's and sotalol therapy was started. In the 36-48 hours of sotalol therapy, cardioversion was performed again with 2 joule/ $\mathrm{kg}$ for the second time as AFl continued. After that, normal sinus rhythm was detected on ECG. At postnatal day 10, the patient was discharged with sotalol therapy. No AFI was detected in the 1-year follow up and corrected QT (QTc), Holter ECG and echocardiography (ECHO) were all found to be normal. Therefore, sotalol therapy was stopped.

\section{Case 2}

A term, male infant was born by C-section because of fetal distress from the first pregnancy of 27-year-old mother. At the physical examination, both tachypnea $(60 / \mathrm{min})$ and tachycardia (250/bpm) were determined. Nasal continuous positive airway pressure (NCPAP) was performed. As ECG showed supraventricular tachycardia (SVT), intravenous adenosine with a dosage of $0.1 \mathrm{mg} / \mathrm{kg}$ was

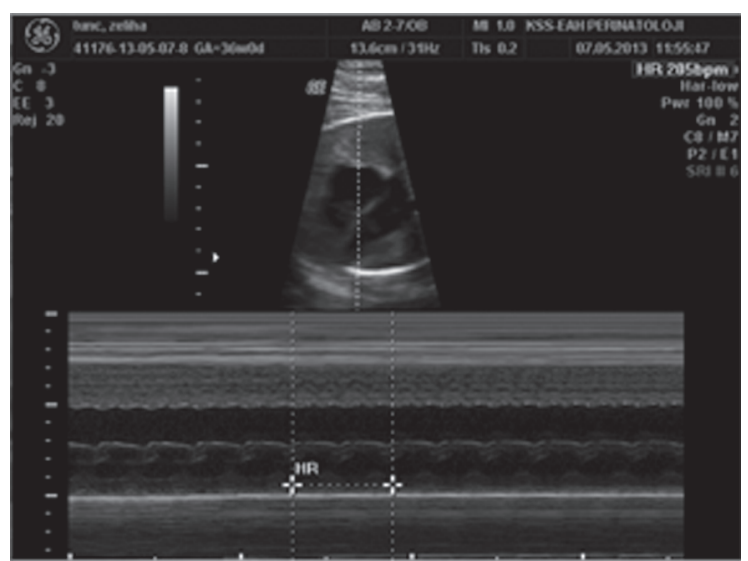

Fig. 1. Fetal ultrasound demonstrated arrhythmia (36th gestational week).

Ventricular rate: 205/min, 2-3:1 AV block administered. Because of persistence of SVT, cardioversion was performed for once. After conversion to normal sinus rhythm, propranolol therapy was started. At the third hour of propranolol therapy, SVT recurred; so second cardioversion was performed successfully with the establishment of sinus rhythm. At postnatal day 2, weaning from NCPAP to room air was performed. SVT did not occur and the infant was discharged at the 7th day of life with propranolol therapy. AFI did not repeat in the 1-year follow up and corrected QT (QTc), Holter ECG and echocardiography (ECHO) were all found to be normal. Therefore, therapy was ceased.

\section{Case 3}

A female neonate was born at 34 weeks of gestational age by $\mathrm{C}$-section because of hydrops fetalis from the first pregnancy of 22 -yearold mother. Her birth weight was 2,620 g. She was intubated in delivery room due to respiratory distress. At her first physical exam, in addition to tachypnea, her heart rate was found as $254 / \mathrm{bpm}$. As ECG detected AFl, adenosine was administered for twice. After initiation of propranolol therapy, cardioversion was also performed due to the recurrent AFI's. As AFl remained resistant to these therapies, amiodarone therapy was started. Normal sinus rhythm was detected after 1 hour of amiodarone administration. After 24 hours without AFl attack, intravenous amiodarone therapy was replaced with oral treatment. At the 14 th day of follow up, only two short SVT attacks were detected on ECG monitor which lasted for 2 or 5 minutes and resolved spontaneously. The patient was discharged at 18th day of life and in good general state with propranolol and amiodarone therapy. AFI did not repeat during the first year of follow up. Corrected

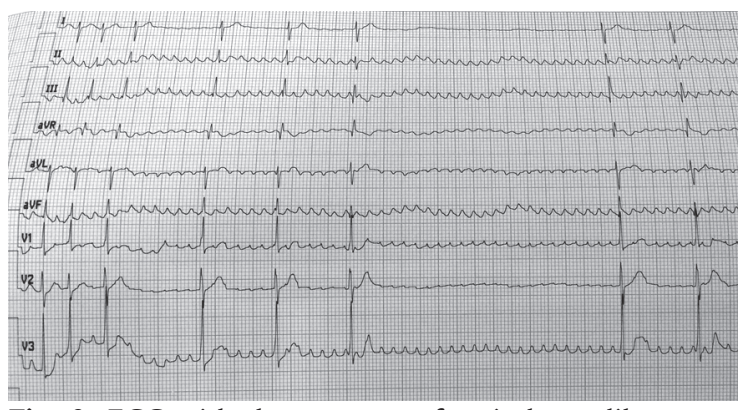

Fig. 2. ECG with the presence of typical saw like waves of flutter (atrial rate $485 / \mathrm{bpm}$, ventricular rate $225 / \mathrm{bpm}$ ). 
QT (QTc), Holter ECG and echocardiography (ECHO) were all found to be normal in routine controls therefore, therapy was caesed.

\section{Discussion}

Atrial flutter in newborn generally occurs in the first 7 days of life. Sex distribution is known to be equal. ${ }^{3}$ Atrioventricular re-entry is the most common mechanism determined for supraventricular tachycardia in both the fetus and newborn. ${ }^{8}$

Fetuses and neonates with atrial flutter or ectopic atrial tachycardia are more likely to be macrosomic or be born to diabetic mothers than the general population. ${ }^{9}$

But neither macrosomia nor gestational diabetes was present in our cases. Important factors for clinical course are beginning of the signs, duration of $\mathrm{AFl}$, and degree of ventricle response to AFl. While the patient is not stabile hemodinamically, cardioversion is the treatment of choice, but if the clinical state is stable, antiarrhythmic drugs are suggested. ${ }^{3,4}$ Our first case had no cardiac abnormality or clinical symptom of heart failure. Majority of fetal tachycardia detected before 36 weeks of gestation can be treated by maternal administration of antiarrhythmic drugs such as digoxin and dexamethasone. ${ }^{10}$ Dexamethasone is recommended in case of severe hydrops fetalis but its neurologic side effects should be taken into consideration. Our cases were detected after 36 th gestational week so maternal therapy did not start. After 36th gestational week postnatal medications, transesophageal overdrive pacing, or synchronized direct current cardioversion (DCC) might be the choices of treatment. ${ }^{11}$ Cardioversion for neonatal AFl is often successful with as little as $0.25-0.5 \mathrm{~J} / \mathrm{kg}$ with the current biphasic devices. ${ }^{12}$ However it is use in neonates has not been approved yet, ibutilide is reported to be effective in some cases of $\mathrm{AFl} .{ }^{13}$ It is also reported that propafenone therapy and multiple external electrical cardioversion could be successful for refractory neonatal atrial flutter. ${ }^{14}$ Digoxin has been recommended in the treatment of neonatal $\mathrm{AFl}$. But because of the raised risk of ventricular tachycardia accompanying to cardioversion after digitalization we did not use digoxin in our case 1 for the first choice.4,7,15 Though patients were stabile hemodinamically and AFl did not last for a long-time, anticoagulant therapy were not required. We used propranolol, cardioversion, sotalol and then cardioversion again. Direct current cardioversion appears to be most effective at establishing sinus rhythm. After these therapies sinusoidal rhythm detected on patient's ECG and his general status went on normal. Different studies reported the success ratio of cardioversion at returning AFl into normal sinusoidal rhythm is to be approximately $90 \% .{ }^{7,16}$ In patient 1 , because of recurrent $\mathrm{AFl}$ episodes after the combination therapy of propranolol and cardioversion, a combination therapy of sotalol and cardioversion were performed then AFl episodes disappeared. Similar to our results, plenty of studies have shown that sotalol is the most effective drug in AFl treatment. ${ }^{6,16,17}$ Dikensoy et al. ${ }^{6}$ reported a fetal AFl case healed by the use of sotalol confidently after failing with digoxin. It is pointed out that sotalol is a good second choice of antiarrhythmic agent to use safely at perinatal term because it has no inotropic effect.6,18 In accordance with the recent literature, successful results of our cases might be supportive for the combination therapy of propranolol, amiodarone, flecainide and cardioversion in refractory AFl. Therefore, it is being an efficient option of treatment. ${ }^{19}$ Amiodarone is associated with electromechanical dissociation, amiodarone-induced pulmonary toxicity and transient hypothyroidism. ${ }^{20}$ Maternal drug use of cocaine and/or opiate is found to be associated with isolated atrial flutter. ${ }^{21}$ In the second case of ours, maternal drug addiction is thought to be the reason of AFl of the baby. Maternal lithium ingestion is thought to be related with fetal AFl so assessment of all infants born to mothers on lithium treatment during pregnancy should include an electrocardiogram. ${ }^{22}$ Hypophosphatemic familial rickets (vitamin D-resistant rickets) of a female fetus, associated with atrial flutter and congestive heart failure is also reported. ${ }^{23}$

AFl in neonate might be resistant to first step therapies such as beta-blockers (esmolol, propranolol) or digoxin. Therefore secondary agents like flecainide, amiodarone, sotalol and cardioversion, if required, could be influent in perinatal tachyarrhythmia. In addition, close follow-up even after discharge is very important and one should try to keep all follow up appointments. Follow-up is needed to check 
for signs of the arrhythmia recurrence, as well as possible side effects of certain treatments. Infants with AFl generally have an excellent prognosis once in sinus rhythm with a low risk of recurrence, and long-term antiarrhythmic therapy is unlikely to be necessary.

\section{REFERENCES}

1. Badrawi N, Hegazy RA, Tokovic E, Lotfy W, Mahmoud F, Aly H. Arrhythmia in the neonatal intensive care unit. Pediatr Cardiol 2009; 30: 325-330.

2. Southall DP, Johnson AM, Shinebourne EA, Johnston PG, Vulliamy DG. Frequency and outcome of disorders of cardiac rhythm and conduction in a population of newborn infants. Pediatrics 1981; 68: 58-66.

3. James H. Moller JH, Davachi F, Anderson RS. Atrial flutter in infancy. J Pediatr 1999; 75: 643-651.

4. Tunaoğlu FS, Yıldırım A, Akça A. Atriyal flattere neden olan hamak mitral kapak: Üç aylık bebek olgu. Türk Pediatri Arşivi 2013; 48: 244-247.

5. Luewan S, Sittiwangkul R, Srisupundit K, Tongsong T. Perinatal treatment of refractory atrial flutter with hydrops fetalis: a case report. J Med Assoc Thai 2011; 9: $878-881$.

6. Dikensoy E, Başpınar O, Balat Ö. Fetal atrial flatterli bir olguda sotalol tedavisi. Perinatoloji Dergisi 2008; 16: $104-108$

7. Özdemir R, Altuğ N, Alyamaç-Dizdar E, ve ark. Prematüre bir yenidoğanda kardiyoversiyon ile tedavi edilen atriyal flatter olgusu. Türkiye Çocuk Hastalıkları Dergisi 2013; 1: 47-49.

8. Wren C. Cardiac arrhythmias in the fetus and newborn. Semin Fetal Neonatal Med 2006; 11: 182-190.

9. Pike JI, Krishnan A, Kaltman J, Donofrio MT. Fetal and neonatal atrial arrhythmias: an association with maternal diabetes and neonatal macrosomia. Prenat Diagn 2013; 33: 1152-1157.

10. Sacks JH, Samai C, Gomez K, Kanaan U. Maternal antibody-associated fetal second-degree heart block and atrial flutter: Case report and review. Pediatr Cardiol 2013; 34: 2040-2043.

11. Lulić Jurjević R, Podnar T, Vesel S. Diagnosis, clinical features, management, and post-natal follow-up of fetal tachycardias. Cardiol Young 2009; 19: 486-493.
12. Ceresnak SR, Starc TJ, Hordof AJ, Pass RH, Bonney WJ, Liberman L. Elevated impedance during cardioversion in neonates with atrial flutter. Pediatr Cardiol 2009; 30: $436-440$.

13. Prasad D, Snyder C, Ashwath R. Ibutilide therapy in the conversion of atrial flutter in neonates. Heart Rhythm 2013; 10: 1231-1233.

14. Gulletta S, Rovelli R, Fiori R, Bella PD. Multiple external electrical cardioversions for refractory neonatal atrial flutter. Pediatr Cardiol 2012; 33: 354-356.

15. Kleiger R, Lown B. Cardioversion and digitalis: II Clinical studies. Circulation 1966; 33: 878-887.

16. Lisowski LA, Verheijen PM, Benatar AA, et al Atrial flutter in the perinatal age group: Diagnosis, management and outcome. J Am Coll Cardiol 2000; 35: 771-777.

17. Wu TH, Huang LC, Ho M, Lee CC, Chiu TH, Hung YC. Fetal atrial flutter: a case report and experience of sotalol treatment. Taiwanese J Obstet Gynecol 2006; 45: 79-82.

18. Knudson JD, Cannon BC, Kim JJ, Moffett BS. High-dose sotalol is safe and effective in neonates and infants with refractory supraventricular tachyarrhythmias. Pediatr Cardiol 2011; 32: 896-903.

19. Ergül Y, Özyılmaz İ, Saygı M, Tola HT, Akdeniz C, Tuzcu V. The use of flecainide in critical neonates and infants with incessant supraventricular tachycardias. Turk Kardiyol Dern Ars 2015; 43: 607-612.

20. Knirsch W, Kretschmar O, Vogel M, Uhlemann F, Bauersfeld U. Successful treatment of atrial flutter with amiodarone in a premature neonate. Case report and literature review. Adv Neonatal Care 2007; 7: 113-121.

21. Gad A, Morelli P, Decristofaro J. Perinatal isolated atrial flutter associated with maternal cocaine and opiate use in a late preterm infant. J Matern Fetal Neonatal Med 2010; 23: 1062-1065.

22. Wilson N, Forfar JD, Godman MJ. Atrial flutter in the newborn resulting from maternal lithium ingestion. Arch Dis Child 1983; 58: 538-539.

23. Vintzileos AM, Campbell WA, Soberman SM, Nochimson DJ. Fetal atrial flutter and X-linked dominant vitamin D-resistant rickets. Obstet Gynecol 1985; 65: 39-44. 